\title{
Olanzapine and Clozapine Increase the GABAergic Neuroactive Steroid Allopregnanolone in Rodents
}

\author{
Christine E Marx*, , Margaret J VanDoren ${ }^{2,3}$, Gary E Duncan ${ }^{2}$, Jeffrey A Lieberman ${ }^{2}$ and A Leslie Morrow ${ }^{2,3,4}$ \\ 'Department of Psychiatry and Behavioral Sciences, Duke University Medical Center and Durham VA Medical Center, Durham, North Carolina, \\ USA; ${ }^{2}$ Department of Psychiatry, University of North Carolina, Chapel Hill, North Carolina 27599, USA; ${ }^{3}$ Center for Alcohol Studies, University of \\ North Carolina, Chapel Hill, North Carolina 27599, USA; ${ }^{4}$ Department of Pharmacology, University of North Carolina, Chapel Hill, North Carolina \\ 27599, USA
}

\begin{abstract}
The neuroactive steroid allopregnanolone is a potent $\gamma$-aminobutyric acid type $A\left(G A B A_{A}\right)$ receptor modulator with anxiolytic and anticonvulsant effects. Olanzapine and clozapine also have anxiolytic-like effects in behavioral models. We therefore postulated that olanzapine and clozapine would elevate allopregnanolone levels, but risperidone and haloperidol would have minimal effects. Male rats received intraperitoneal olanzapine $(2.5-10.0 \mathrm{mg} / \mathrm{kg})$, clozapine $(5.0-20.0 \mathrm{mg} / \mathrm{kg})$, risperidone $(0.1-1.0 \mathrm{mg} / \mathrm{kg})$, haloperidol $(0.1-1.0 \mathrm{mg} /$ $\mathrm{kg}$ ), or vehicle. Cerebral cortical allopregnanolone and peripheral progesterone and corticosterone levels were determined. Adrenalectomized animals were also examined. Both olanzapine and clozapine increased cerebral cortical allopregnanolone levels, but neither risperidone nor haloperidol had significant effects. Olanzapine and clozapine also increased serum progesterone and corticosterone levels. Adrenalectomy prevented olanzapine- and clozapine-induced elevations in allopregnanolone. Allopregnanolone induction may contribute to olanzapine and clozapine anxiolytic, antidepressant, and mood-stabilizing actions. Alterations in this neuroactive steroid may result in the modulation of GABAergic and dopaminergic neurotransmission, potentially contributing to antipsychotic efficacy.

Neuropsychopharmacology (2003) 28, I-13. doi:I0.1038/sj.npp. I3000I5
\end{abstract}

Keywords: neuroactive steroid; allopregnanolone; olanzapine; clozapine; GABA; progesterone

\section{INTRODUCTION}

The neuroactive steroid allopregnanolone ( $3 \alpha$-hydroxy- $5 \alpha$ pregnan-20-one) is synthesized de novo in the brain from cholesterol or from peripheral steroid precursors such as progesterone, and in the adrenals and gonads (Purdy et al, 1991). It is a positive allosteric modulator of $\gamma$-aminobutyric acid type $A\left(G_{A B A}\right)$ receptors, potentiating GABAergic neurotransmission in a manner that is 20 -fold more potent than benzodiazepines and 200-fold more potent than barbiturates (Majewska et al, 1986; Morrow et al, 1987, 1990). Allopregnanolone demonstrates marked anxiolytic (Crawley et al, 1986; Wieland et al, 1991) and anticonvulsant activity (Kokate et al, 1994, 1996; Devaud et al, 1995), likely secondary to $\mathrm{GABA}_{\mathrm{A}}$ receptor potentiation. Recent evidence also suggests that allopregnanolone may be

\footnotetext{
*Correspondence: Dr CE Marx, Department of Psychiatry and Behavioral Sciences, Duke University Medical Center and Durham VA Medical Center, Mental Health Service Line (I I6A), 508 Fulton Street, Room CI0023, Durham, NC 27705, USA, Tel: + I 919286 0411 ext. 5112 (hospital), + I 9192860411 ext. 7426 (laboratory), Fax: + I 919 416 5832, E-mail: marx000।@mc.duke.edu Received 19 December 200 I; revised I4 May 2002; accepted 20 June 2002
}

relevant to antipsychotic drug action and schizophrenia pathophysiology (Marx et al, 2000).

We have demonstrated previously that olanzapine increases cerebral cortical allopregnanolone levels in male rats to levels known to affect GABAergic neurotransmission (Marx et al, 2000). Since olanzapine also demonstrates anxiolytic-like activity in animal behavioral paradigms (Arnt and Skarsfeldt, 1998), we hypothesized that olanzapine-induced elevations in the endogenous anxiolytic neuroactive steroid allopregnanolone may contribute to these effects. In this study, we hypothesize that the antipsychotic clozapine also elevates cerebral cortical allopregnanolone levels in rats, since clozapine has anxiolytic-like effects in animals. For example, both clozapine and olanzapine increase punished responding in a conflict schedule rodent anxiety model, but risperidone and haloperidol have no significant effects (Moore et al, 1994). We therefore hypothesize that an elevation in the anxiolytic neuroactive steroid allopregnanolone will not be present following risperidone or haloperidol administration, since these antipsychotic agents generally do not demonstrate anxiolytic effects in animal behavioral models (Arnt and Skarsfeldt, 1998; Moore et al, 1994).

In addition to anxiolytic actions, allopregnanolone appears to have antidepressant effects (Uzunova et al, 
1998; Romeo et al, 1998). In patients with major depression receiving fluoxetine or fluvoxamine, cerebrospinal fluid allopregnanolone levels normalized with antidepressant treatment and correlated with improvement in depressive symptomatology (Uzunova et al, 1998). Since olanzapine (Tollefson et al, 1997, 1998; Shelton et al, 2001) and clozapine (Meltzer and Okayli, 1995; Meltzer 2001) also appear to have antidepressant actions, it is possible that olanzapine- or clozapine-induced elevations in this neuroactive steroid may contribute to these effects. Rodent work examining fluoxetine-induced elevations in allopregnanolone demonstrates that the effect is present to the same extent in both adrenalectomized and intact animals, suggesting fluoxetine-induced de novo allopregnanolone biosynthesis in the brain (Uzunov et al, 1996). To determine if antipsychotic-induced elevations in cerebral cortical allopregnanolone are similarly independent of adrenal progesterone or allopregnanolone production, adrenalectomized animals were examined to clarify the mechanism of this neuroactive steroid alteration.

An extensive literature documents the anticonvulsant effects of allopregnanolone utilizing a number of animal seizure models (Kokate et al, 1994, 1996; Belelli et al, 1989; Gasior et al, 1997; Devaud et al, 1995). Since anticonvulsants are frequently used in the pharmacological treatment of psychiatric illnesses such as bipolar disorder, and since both olanzapine (Tohen et al, 1999, 2000) and clozapine (Suppes et al, 1999; Green et al, 2000) are effective antimanic agents, antipsychotic-induced elevations in this neuroactive steroid may contribute to this clinical effect. In summary, the GABAergic neuroactive steroid allopregnanolone has anxiolytic, antidepressant, and anticonvulsant effects, and the atypical antipsychotics olanzapine and clozapine demonstrate anti-anxiety, antidepressant, and antimanic actions. Allopregnanolone induction could therefore be relevant to these therapeutic actions.

In the following experiments, we determined the specificity of antipsychotic-induced alterations in the GABAergic neurosteroid allopregnanolone by administering olanzapine, clozapine, risperidone, or haloperidol intraperitoneally at pharmacologically relevant doses to male rats. We also investigated serum progesterone and corticosterone levels following antipsychotic treatment to determine the specificity of these steroid alterations in rodents, and to determine if peripheral serum progesterone levels are correlated with cerebral cortical allopregnanolone levels.

\section{METHODS}

All experiments were conducted in accordance with National Institutes of Health Guidelines under Institution Animal Care and Use Committee-approved protocols. Male Sprague-Dawley rats (200-250 mg) were purchased from Harlan (Indianapolis, IN). Rats were housed three per cage and placed on a 12-h light-dark cycle (lights on, 6:00 am to 6:00 pm) with ad libitum access to rat chow and water. All rats were handled and habituated to intraperitoneal (i.p.) vehicle injection ( $0.9 \%$ saline) for 5 days prior to the day of the experiment to minimize possible stress-induced steroid increases. All experiments were performed at the beginning of the light cycle between 9:00 am and noon to minimize diurnal steroid fluctuations.

\section{Antipsychotic Administration and Dosing}

Olanzapine (Eli Lilly and Company, Indianapolis, IN), was dissolved in a small amount of $20 \%$ acetic acid $(0.5 \mathrm{ml}$ or less) and then diluted with $0.9 \%$ saline (final acetic acid concentration $0.2 \%$ ). Clozapine (Sigma, St Louis, MO) was prepared in a similar manner. Risperidone (Sigma, St Louis, MO) was dissolved in $45 \% \mathrm{w} / \mathrm{v}$ 2-hydroxypropyl- $\beta$-cyclodextrin (Sigma, St Louis, MO) and then diluted with distilled water (final 2-hydroxypropyl- $\beta$-cyclodextrin concentration 22.5\%). Haloperidol $2.0 \mathrm{mg} / \mathrm{ml}$ liquid (Pai Pharmaceutical Associates Inc., Greenville, SC) was diluted with $0.9 \%$ saline. The vehicle consisted of $0.2 \%$ acetic acid in $0.9 \%$ saline.

On the day of the experiment, antipsychotics were administered i.p. at the following doses: olanzapine $0,2.5$, 5.0 , or $10.0 \mathrm{mg} / \mathrm{kg}$, clozapine $0,5.0,10.0$, or $20.0 \mathrm{mg} / \mathrm{kg}$, risperidone $0,0.1,0.5$, or $1.0 \mathrm{mg} / \mathrm{kg}$, and haloperidol $0,0.1$, 0.5 , or $1.0 \mathrm{mg} / \mathrm{kg}, n=6-11$ animals per treatment condition. Dose-response experiments were repeated two additional times for each antipsychotic. Results were consistently replicated, and therefore the three dose-response experiments for each antipsychotic were combined, final $n=17-$ 31 per treatment condition.

In designing these experiments, we targeted rodent dosing strategies relevant to antipsychotic dosing in human subjects (Mukherjee et al, 2001; Kapur et al, 1998, 1999) and consistent with doses utilized in the existing rodent literature (Duncan et al, 2000; Kinkead et al, 2000; Atkins et al, 1999; Zhang et al, 2000). Therapeutic response is frequently associated with $\mathrm{D}_{2}$ receptor occupancy of approximately $60-70 \%$ in humans, but $\mathrm{D}_{2}$ occupancies greater than $80 \%$ are associated with increased extrapyramidal side effects. Both haloperidol and risperidone $0.1 \mathrm{mg} / \mathrm{kg}$ doses produce striatal $\mathrm{D}_{2}$ receptor occupancies that exceed $80 \%$ in rodents (Mukherjee et al, 2001). In addition, the reported $\mathrm{ED}_{50}$ values for risperidone to block behavioral effects of dopamine agonists are between 0.06 and $0.1 \mathrm{mg} / \mathrm{kg}$ (Janssen et al, 1988; Megens et al, 1994; Arnt, 1995). Similarly, olanzapine (Bymaster et al, 1996) and clozapine (Mukherjee et al, 2001) dose ranges in this study are known to produce rodent $\mathrm{D}_{2}$ receptor occupancies comparable to $\mathrm{D}_{2}$ occupancies demonstrated in humans receiving these compounds (Kapur et al, 1998, 1999).

Olanzapine, clozapine, and risperidone are also potent $5 \mathrm{HT}_{2}$ antagonists in the dose ranges utilized in this study (Bymaster et al, 1996), corresponding to the extent of $5 \mathrm{HT}_{2}$ blockade observed in human subjects (Kapur et al, 1998, 1999). For blocking $5 \mathrm{HT}_{2 \mathrm{~A}}$-mediated responses in vivo, $\mathrm{ED}_{50}$ values for risperidone are $0.02-0.03 \mathrm{mg} / \mathrm{kg}$ (Janssen et al, 1988; Megens et al, 1994; Zhang and Bymaster, 1999). The highest risperidone dose of $1.0 \mathrm{mg} / \mathrm{kg}$ utilized in this study is, therefore, a high dose of this drug with regard to $\mathrm{D}_{2}$ and $5 \mathrm{HT}_{2}$ antagonism, two pharmacological properties likely relevant to therapeutic response. Finally, the antipsychotic dose ranges utilized in these experiments are also consistent with prior dosing strategies to investigate anxiolytic-like effects in rodent behavioral models (Moore et al, 1992; Wiley et al, 1993; Inoue et al, 1996). Rodent investigations examining clozapine anxiolytic-like effects utilized maximal clozapine doses of $5.0-10.0 \mathrm{mg} / \mathrm{kg}$ (Spealman and Katz, 1980; Moore et al, 1994; Inoue et al, 1996). 
To ensure an adequate dose range for this antipsychotic, we also included a $20.0 \mathrm{mg} / \mathrm{kg}$ clozapine dose.

\section{Tissue Procurement}

Rats were killed by decapitation $1 \mathrm{~h}$ following i.p. antipsychotic administration. The cerebral cortex was rapidly dissected on ice and stored at $-80^{\circ} \mathrm{C}$ until radioimmunoassay (RIA) determination. Trunk blood was collected for serum progesterone and corticosterone determination and stored on ice until centrifugation for serum collection.

\section{Radioimmunoassays}

Allopregnanolone levels were measured in the cerebral cortex as described previously (Janis et al, 1998; VanDoren et al, 2000) with a modification of the methods of Purdy et al (1990). Allopregnanolone was extracted from individual cerebral cortical hemispheres prior to RIA determination. Recovery was monitored by the incorporation of $4000 \mathrm{dpm}$ of $\left[{ }^{3} \mathrm{H}\right]$ allopregnanolone. Extraction efficiency ranged between 95 and 100\%. Anti-allopregnanolone antibody was kindly provided by CoCensys Inc. (Irvine, CA). This antiserum has minimal crossreactivity with other circulating steroids (Finn and Gee, 1994; Janis et al, 1998). Crossreactivity with allopregnanolone $3 \beta$ stereoisomers ( $3 \beta$-hydroxy- $5 \alpha$-pregnan-20-one and $3 \beta$-hydroxy- $5 \beta$-pregnan-20-one) is minimal (2.8 and $0.5 \%$, respectively). Crossreactivity with the allopregnanolone $5 \beta$ stereoisomer ( $3 \alpha$-hydroxy- $5 \beta$-pregnan-20-one) is $6.6 \%$. Although this $5 \beta$ stereoisomer is present in humans, it is present in very low concentrations or undetectable in rats. Sample values were compared to a concurrently run allopregnanolone standard curve produced using a one-site competition model (Prism2; GraphPad, San Diego, CA). Sample values were adjusted to account for the previously determined extraction efficiency. The sensitivity of the assay was $20 \mathrm{pg} / \mathrm{tube}$.

Serum progesterone and corticosterone were assayed in duplicate with commercially available RIA kits utilizing ${ }^{125} \mathrm{I}$ progesterone and ${ }^{125} \mathrm{I}$-corticosterone (ICN Pharmaceuticals, Costa Mesa, CA) according to the manufacturer's instructions. The limits of detection for the progesterone and corticosterone assays were 0.1 and $10 \mathrm{ng} / \mathrm{ml}$, respectively. Serum progesterone levels were diluted prior to progesterone determination to achieve values within the standard curve of the commercial kit.

\section{Adrenalectomy Experiments}

Male adrenalectomized and sham-operated rats were purchased from Harlan (Indianapolis, IN). Experiments were performed 5-6 days following surgery (and 1-2 days following arrival to the animal colony at our institution). Adrenalectomized animals received $0.9 \%$ saline instead of water ad libitum. Sham-operated animals received water ad libitum. All animals had free access to rat chow. On the day of the experiment, adrenalectomized animals were injected i.p. with olanzapine $10.0 \mathrm{mg} / \mathrm{kg}$ (prepared as described previously) or vehicle $(0.2 \%$ acetic acid in $0.9 \%$ saline $)$, and sham-operated animals were injected i.p. with either olanzapine $10.0 \mathrm{mg} / \mathrm{kg}$ or vehicle, $n=9-11$ animals per condition. The same experiment was performed utilizing clozapine $20.0 \mathrm{mg} / \mathrm{kg}$ as the antipsychotic of interest instead of olanzapine. Rats were decapitated $1 \mathrm{~h}$ following i.p. antipsychotic or vehicle injection, and cerebral cortex and trunk blood were collected as described above.

\section{Statistics}

Statistical analysis of dose-response antipsychotic experiment results was conducted by ANOVA, including post hoc Dunnett tests. Linear regression analysis was used to determine Pearson's correlation coefficients. Analysis of the adrenalectomy experiments was conducted utilizing two-tailed $t$-tests. All data are expressed as the mean \pm standard error of the mean (SEM).

\section{RESULTS}

\section{Olanzapine- and Clozapine-Induced Alterations in Cerebral Cortical Allopregnanolone}

Cerebral cortical allopregnanolone levels were markedly increased $60 \mathrm{~min}$ following i.p. olanzapine $(2.5-10.0 \mathrm{mg} / \mathrm{kg})$ and i.p. clozapine $(5.0-20.0 \mathrm{mg} / \mathrm{kg})$ administration in male Sprague-Dawley rats (Figures $1 \mathrm{a}$ and 2a). Elevations in allopregnanolone were most pronounced following olanzapine treatment. Changes in cerebral cortical allopregnanolone levels induced by olanzapine and clozapine were dose-dependent and specific to these two antipsychotics. Olanzapine $5.0 \mathrm{mg} / \mathrm{kg}(n=21)$ and $10.0 \mathrm{mg} / \mathrm{kg} \quad(n=30)$ significantly increased cerebral cortical allopregnanolone levels to $2.875 \pm 0.531$ and $3.68 \pm 0.433 \mathrm{ng} / \mathrm{g}$, respectively, compared to vehicle levels $(n=30)$ of $1.192 \pm 0.278 \mathrm{ng} / \mathrm{g}$ (ANOVA: $p<0.0001 ; \mathrm{F}=11.80 ; \mathrm{df}=3,97 ; n=20-30$ animals per condition; post hoc Dunnett tests: ${ }^{*} p<0.01$ for olanzapine 5.0 and $10.0 \mathrm{mg} / \mathrm{kg}$ conditions). Clozapine $20.0 \mathrm{mg} / \mathrm{kg}(n=21)$ significantly increased cerebral cortical allopregnanolone levels to $2.655 \pm 0.473 \mathrm{ng} / \mathrm{g}$ compared to vehicle levels $(n=28)$ of $1.214 \pm 0.202 \mathrm{ng} / \mathrm{g}$ (ANOVA: $p=0.0043 ; \mathrm{F}=4.742 ; \mathrm{df}=3,80 ; n=17-28$ animals per condition; post hoc Dunnett tests: ${ }^{\star *} p<0.01$ for clozapine $20.0 \mathrm{mg} / \mathrm{kg}$ condition). In contrast, i.p. risperidone did not alter cerebral cortical allopregnanolone in male SpragueDawley rats at any of the doses tested compared to vehicle (Figure 3a) (ANOVA: $p=0.0042 ; \mathrm{F}=4.752 ; \mathrm{df}=3,80$; $n=18-28$ animals per condition; post hoc Dunnett tests: $p>0.05$ for all risperidone-treated conditions). Similarly, haloperidol did not alter cerebral cortical allopregnanolone formation at any of the doses tested compared to vehicle (Figure 3b) (ANOVA: $p=0.0259 ; \mathrm{F}=3.253 ; \mathrm{df}=3,81$; $n=18-28$ per condition; post hoc Dunnett tests: $p>0.05$ for all haloperidol-treated conditions).

\section{Antipsychotic-Induced Alterations in Serum Progesterone Precursor}

Serum progesterone precursor was dramatically increased 60 min following olanzapine and clozapine i.p. administration up to 58- and 47-fold, respectively (Figures $1 \mathrm{~b}$ and $2 \mathrm{~b}$ ). Serum progesterone alterations induced by olanzapine and clozapine were dose-dependent and highly significant. Olanzapine treatment had the most pronounced effects on serum progesterone in male rats. Olanzapine $5.0 \mathrm{mg} / \mathrm{kg}$ 

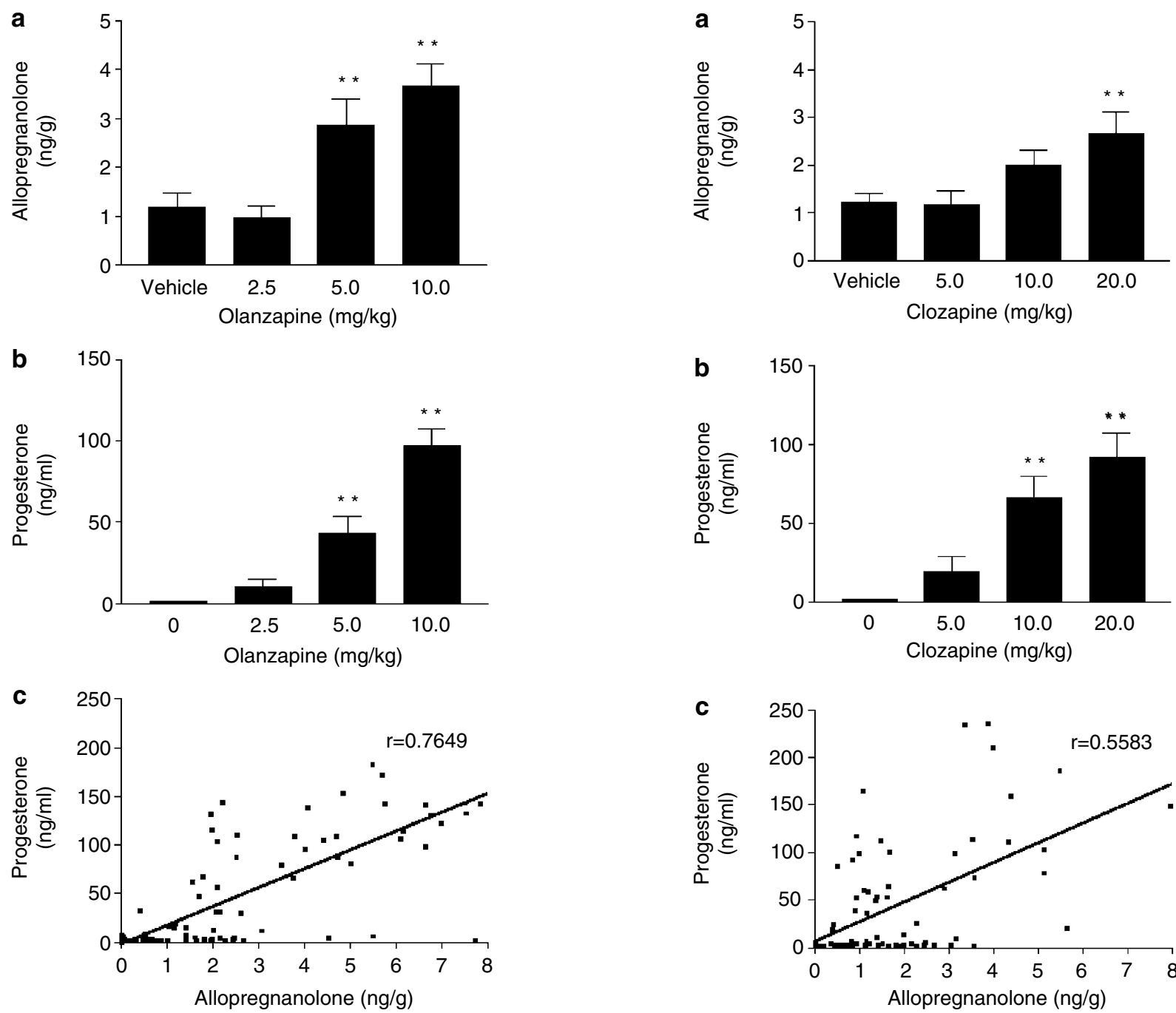

Figure I (a) Olanzapine dose-dependently increases cerebral cortical allopregnanolone, ANOVA $p<0.0001 ; F=11.80 ;$ df 3, 97; $n=20-30$ animals per condition; post hoc Dunnett tests: ** $p<0.0$ I for olanzapine $5.0 \mathrm{mg} / \mathrm{kg}$ condition $(n=2 \mathrm{l})$ and $* * p<0.0 \mathrm{l}$ for olanzapine $10.0 \mathrm{mg} / \mathrm{kg}$ condition $(n=30)$. (b) Olanzapine dose-dependently increases serum progesterone, ANOVA $p<0.000 \mathrm{I} ; \mathrm{F}=31.65 ; \mathrm{df} 3,98 ; n=20-3 \mathrm{I}$ animals per condition; post hoc Dunnett tests: ** $p<0.0$ I for olanzapine $5.0 \mathrm{mg} / \mathrm{kg}$ condition $(n=2 \mathrm{I})$ and $* * x<0.0 \mathrm{I}$ for olanzapine $10.0 \mathrm{mg} / \mathrm{kg}$ condition $(n=3 \mathrm{I})$. (c) Cerebral cortical allopregnanolone and serum progesterone are positively correlated in olanzapine-treated animals, Pearson correlation coefficient $r=0.7649$; $p<0.000$ I; number of paired values $=101$.

$(n=21)$ and $10.0 \mathrm{mg} / \mathrm{kg}(n=31)$ elevated serum progesterone levels to $42.83 \pm 11.15$ and $97.00 \pm 10.69 \mathrm{ng} / \mathrm{ml}$, respectively, compared to vehicle levels $(n=30)$ of $1.684 \pm 0.162 \mathrm{ng} / \mathrm{ml}$ (Figure 1b) (ANOVA: $p<0.0001$; $\mathrm{F}=31.65 ; \mathrm{df}=3,98 ; n=20-31$ animals per condition; post hoc Dunnett tests: ${ }^{* *} p<0.01$ for olanzapine 5.0 and $10.0 \mathrm{mg} /$ $\mathrm{kg}$ conditions). Clozapine $10.0 \mathrm{mg} / \mathrm{kg}(n=18)$ and $20.0 \mathrm{mg} /$ $\mathrm{kg}(n=20)$ elevated serum progesterone levels to $66.62 \pm 13.62$ and $92.30 \pm 15.29 \mathrm{ng} / \mathrm{ml}$, respectively, compared to vehicle levels $(n=27)$ of $1.965 \pm 0.216 \mathrm{ng} / \mathrm{ml}$ (Figure 2b) (ANOVA: $p<0.0001 ; \quad \mathrm{F}=17.35 ; \mathrm{df}=3,78$; $n=17-27$ animals per condition; post hoc Dunnett tests: ${ }^{* *} p<0.01$ for clozapine 10.0 and $20.0 \mathrm{mg} / \mathrm{kg}$ conditions).

Risperidone also had significant effects on serum progesterone levels, but elevations were less robust than

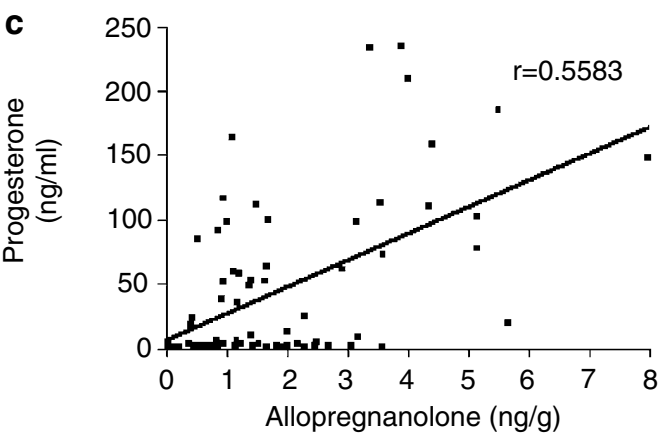

Figure 2 (a) Clozapine dose-dependently increases cerebral cortical allopregnanolone, ANOVA $p=0.0043 ; F=4.742 ; \mathrm{df} 3,80 ; n=17-28$ animals per condition; post hoc Dunnett: ** $p<0.0$ I for clozapine $20.0 \mathrm{mg} /$ $\mathrm{kg}$ condition $(n=2 \mathrm{I})$. (b) Clozapine dose-dependently increases serum progesterone, ANOVA $p<0.000 \mathrm{I} ; \mathrm{F}=17.35 ; \mathrm{df} 3,78 ; n=17-27$ animals per condition; post hoc Dunnett tests: $* * * 0.01$ for clozapine $10.0 \mathrm{mg} / \mathrm{kg}$ condition $(n=18)$ and $* * * 0.01$ for clozapine $20.0 \mathrm{mg} / \mathrm{kg}$ condition $(n=20)$. (c) Cerebral cortical allopregnanolone and serum progesterone are positively correlated in clozapine-treated animals, Pearson correlation coefficient $r=0.5583 ; p<0.000$ I; number of paired values $=80$.

olanzapine- or clozapine-induced alterations in this steroid (Figure 3c) Risperidone $1.0 \mathrm{mg} / \mathrm{kg}(n=20)$ elevated serum progesterone 20 -fold to $41.29 \pm 16.45 \mathrm{ng} / \mathrm{ml}$ compared to vehicle levels $(n=27)$ of $2.070 \pm 0.203 \mathrm{ng} / \mathrm{ml}$ (Figure 3c) (ANOVA: $p=0.0019 ; \mathrm{F}=5.453 ; \mathrm{df}=3,79 ; n=18-27$ animals per condition; post hoc Dunnett tests: ${ }^{* *} p<0.01$ for risperidone $1.0 \mathrm{mg} / \mathrm{kg}$ condition). In contrast, haloperidol had very modest effects on serum progesterone levels compared to olanzapine-, clozapine-, and risperidoneinduced alterations (Figure 3d). Haloperidol $1.0 \mathrm{mg} / \mathrm{kg}$ $(n=20)$ elevated serum progesterone levels 2.7 -fold to $5.533 \pm 2.072 \mathrm{ng} / \mathrm{ml}$ compared to vehicle levels $(n=27)$ of $2.060 \pm 0.205 \mathrm{ng} / \mathrm{ml} \quad$ (ANOVA: $p=0.0463 ; \quad \mathrm{F}=2.7841$; $\mathrm{df}=3,78 ; n=17-27$ animals per condition; post hoc Dunnett tests: ${ }^{\star} p<0.05$ for haloperidol $1.0 \mathrm{mg} / \mathrm{kg}$ condition). 

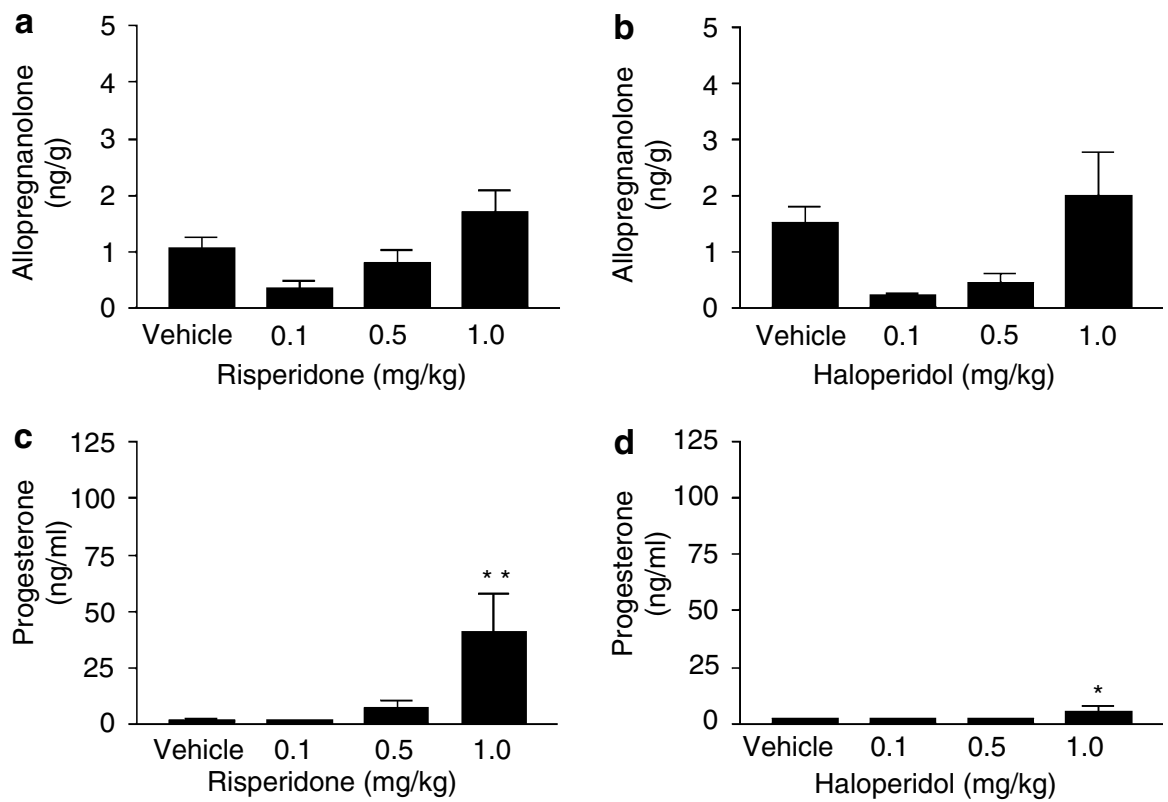

Figure 3 (a) Risperidone does not alter cerebral cortical allopregnanolone, ANOVA $p=0.0042 ; F=4.752 ; d f 3,80 ; n=18-28$ animals per condition; post hoc Dunnett tests: *** $>0.05$ for all risperidone-treated conditions. (b) Haloperidol does not alter cerebral cortical allopregnanolone, ANOVA $p=0.0259 ; F=3.253 \mathrm{df} 3,8 \mathrm{I} ; n=18-28$ animals per condition; post hoc Dunnett tests: $p>0.05$ for all haloperidol-treated conditions. (c) Risperidone increases serum progesterone at the highest dose tested, ANOVA $p=0.0019 ; \mathrm{F}=5.453 ; \mathrm{df} 3,79 ; n=18-27$ animals per condition; post hoc Dunnett: *** $p<0.01$ for risperidone $1.0 \mathrm{mg} / \mathrm{kg}$ condition $(n=20)$. (d) Haloperidol modestly increases serum progesterone at the highest dose tested, ANOVA $p=0.0463 ; \mathrm{F}=2.784 ; \mathrm{df} 3,78 ; n=17-27$ animals per condition; post hoc Dunnett: ${ }^{*} p=0.05$ for haloperidol $1.0 \mathrm{mg} / \mathrm{kg} \mathrm{condition}(\mathrm{n}=20$ ).

\section{Serum Progesterone is Correlated with Cerebral Cortical Allopregnanolone in Olanzapine- and Clozapine-Treated Animals}

Linear regression analysis reveals that serum progesterone and cerebral cortical allopregnanolone levels are positively correlated in olanzapine-treated animals (Figure 1c) (Pearson's correlation coefficient $r=0.7649, p<0.0001$ ), suggesting that serum progesterone may serve as a precursor to cerebral cortical allopregnanolone biosynthesis. Similarly, serum progesterone and cerebral cortical allopregnanolone are also positively correlated in clozapine-treated animals (Figure 2c) (Pearson's correlation coefficient $r=0.5583$, $p<0.0001)$.

\section{Antipsychotic-Induced Alterations in Serum Corticosterone}

Olanzapine and clozapine demonstrated pronounced dosedependent effects on serum corticosterone $60 \mathrm{~min}$ following i.p. injection in male Sprague-Dawley rats, increasing corticosterone up to 10 - and 8.5 -fold, respectively (Table 1). Olanzapine $5.0 \mathrm{mg} / \mathrm{kg}(n=21)$ and $10.0 \mathrm{mg} / \mathrm{kg}$ $(n=31)$ increased serum corticosterone levels to $445.9 \pm 57.0$ and $824.8 \pm 82.6 \mathrm{ng} / \mathrm{ml}$, respectively, compared to vehicle levels $(n=30)$ of $80.46 \pm 12.45 \mathrm{ng} / \mathrm{ml}$ (ANOVA: $p<0.0001, \mathrm{~F}=33.97 ; \mathrm{df}=3,98 ; n=20-31$ animals per treatment condition; post hoc Dunnett tests: ${ }^{* *} p<0.01$ for olanzapine 5.0 and $10.0 \mathrm{mg} / \mathrm{kg}$ conditions), Table 1 . All three clozapine doses tested produced significant effects on serum corticosterone levels. Clozapine $5.0 \mathrm{mg} / \mathrm{kg}(n=18)$, $10.0 \mathrm{mg} / \mathrm{kg} \quad(n=19)$, and $20.0 \mathrm{mg} / \mathrm{kg} \quad(n=21)$ increased serum corticosterone levels to $463.2 \pm 112.4,600.1 \pm 70.4$, and $989.4 \pm 107.9 \mathrm{ng} / \mathrm{ml}$, respectively, compared to vehicle levels $(n=28)$ of $116.4 \pm 34.4 \mathrm{ng} / \mathrm{ml}$ (ANOVA: $p<0.0001, \mathrm{~F}=22.55, \mathrm{df}=3,82$; post hoc Dunnett tests: ${ }_{* *} p<0.01$ for clozapine $5.0,10.0$, and $20.0 \mathrm{mg} / \mathrm{kg}$ conditions) (Table 1).

Risperidone also had significant effects on serum corticosterone, but effects were less pronounced compared to olanzapine- and clozapine-induced alterations in this steroid. Risperidone $1.0 \mathrm{mg} / \mathrm{kg}(n=20)$ increased serum corticosterone levels to $438.5 \pm 85.73 \mathrm{ng} / \mathrm{ml}$ compared to vehicle levels $(n=28)$ of $118.4 \pm 32.2 \mathrm{ng} / \mathrm{ml}$, a 3.7 -fold increase (ANOVA: $p<0.0001, \mathrm{~F}=10.83, \mathrm{df}=3,81 ; n=18$ 28 animals per condition; post hoc Dunnett test: ${ }^{* *} p<0.01$ for risperidone $1.0 \mathrm{mg} / \mathrm{kg}$ condition) (Table 1). Haloperidol $1.0 \mathrm{mg} / \mathrm{kg}(n=20)$ had more modest effects on corticosterone, increasing serum corticosterone levels 2.4-fold up to $284.6 \pm 74.7 \mathrm{ng} / \mathrm{ml}$ compared to vehicle levels $(n=28)$ of $120.7 \pm 34.1 \mathrm{ng} / \mathrm{ml} \quad$ (ANOVA: $p=0.0211 ; \quad \mathrm{F}=3.421$; $\mathrm{df}=3,81 ; \quad n=18-28$ animals per condition; post hoc Dunnett tests: ${ }^{*} p<0.05$ for haloperidol $1.0 \mathrm{mg} / \mathrm{kg}$ condition) (Table 1).

\section{Adrenalectomy Prevents Olanzapine- and Clozapine-Induced Elevations in Cerebral Cortical Allopregnanolone}

Olanzapine $10.0 \mathrm{mg} / \mathrm{kg}$ increases cerebral cortical allopregnanolone in sham-operated animals $(n=11)$ to $2.536 \pm 0.293 \mathrm{ng} / \mathrm{g}$ compared to levels in vehicle-treated sham-operated animals $(n=9)$ of $0.738 \pm 0.1183 \mathrm{ng} / \mathrm{g}$ (twotailed $t$-test: $\left.{ }^{* *} p<0.0001 ; t=6.111 ; \mathrm{df}=18\right)$ (Figure 4a). In contrast, adrenalectomy prevents olanzapine-induced increases in cerebral cortical allopregnanolone levels 
Table I Antipsychotic-induced Alterations in Serum Corticosterone

\begin{tabular}{|c|c|c|c|c|c|}
\hline Treatment & Dose (mg/kg) & $n$ & $\begin{array}{l}\text { Mean Corticosterone } \\
(\mathrm{ng} / \mathrm{ml} \pm \text { SEM) }\end{array}$ & ANOVA & p (post hoc Dunnett) \\
\hline \multirow[t]{4}{*}{ Olanzapine } & Vehicle & 30 & $80.46 \pm 12.45$ & \multirow[t]{4}{*}{$p<0.0001$} & \\
\hline & 2.5 & 20 & $194.0 \pm 59.47$ & & $p>0.05$ \\
\hline & 5.0 & 21 & $4445.9 \pm 57.00$ & & *** $p<0.01$ \\
\hline & 10.0 & 31 & $824.8 \pm 82.56$ & & *** $p<0.01$ \\
\hline \multirow[t]{4}{*}{ Clozapine } & Vehicle & 28 & $116.4 \pm 34.40$ & \multirow[t]{4}{*}{$p<0.0001$} & \\
\hline & 5.0 & 18 & $463.2 \pm 112.4$ & & **** $p>0.01$ \\
\hline & 10.0 & 19 & $600.1 \pm 70.36$ & & **** $p>0.01$ \\
\hline & 20.0 & 21 & $989.4 \pm 107.9$ & & *** $p<0.01$ \\
\hline \multirow[t]{4}{*}{ Risperidone } & Vehicle & 28 & $118.4 \pm 32.24$ & \multirow[t]{4}{*}{$p<0.0001$} & \\
\hline & 0.1 & 18 & $45.82 \pm 6.899$ & & $p>0.05$ \\
\hline & 0.5 & 19 & $169.3 \pm 45.18$ & & $p>0.05$ \\
\hline & 1.0 & 20 & $438.5 \pm 85.73$ & & **** $p<0.01$ \\
\hline \multirow[t]{4}{*}{ Haloperidol } & Vehicle & 28 & $120.7 \pm 34.08$ & \multirow[t]{4}{*}{$p=0.0211$} & \\
\hline & 0.1 & 18 & $102.2 \pm 24.55$ & & $p<0.05$ \\
\hline & 0.5 & 19 & $121.3 \pm 29.42$ & & $p<0.05$ \\
\hline & 1.0 & 20 & $284.6 \pm 74.68$ & & $* p<0.05$ \\
\hline
\end{tabular}
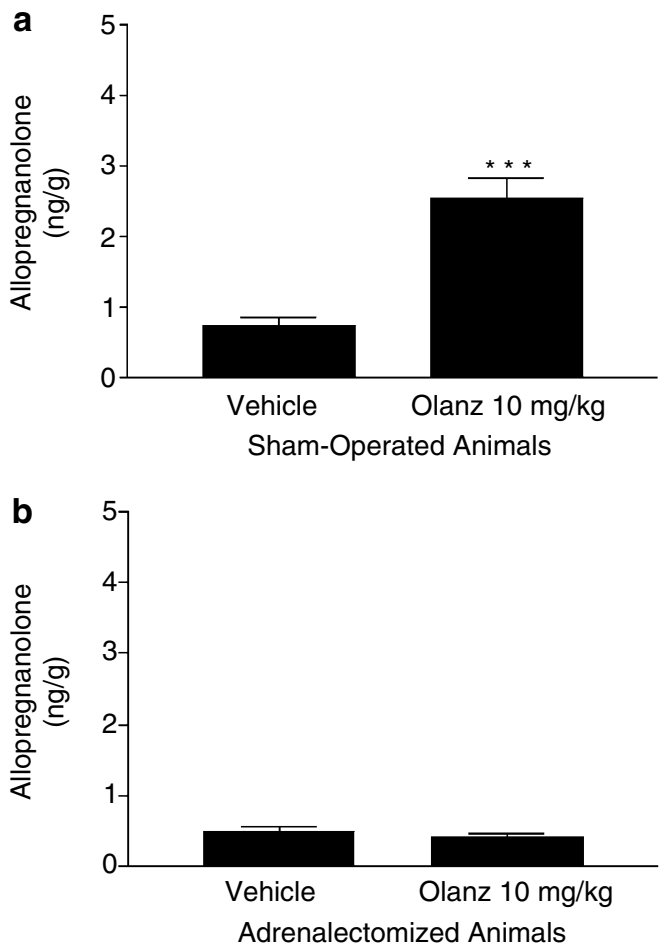

Figure 4 (a) Olanzapine $10.0 \mathrm{mg} / \mathrm{kg}$ increases cerebral cortical allopreg nanolone in sham-operated animals, two-tailed $t$-test ${ }^{*} * * * 0.000$ l; $t=6.111 ; d f=18, n=9-1 \mid$ animals per condition. (b) Adrenalectomy prevents olanzapine-induced increases in cerebral cortical allopregnanolone, two-tailed $t$-test $p=0.4901 ; t=0.7046 ; \mathrm{df}=18, n=10$ animals per condition.

(Figure 4b). Allopregnanolone levels in adrenalectomized animals treated with olanzapine $10.0 \mathrm{mg} / \mathrm{kg}$ were very similar to adrenalectomized animals treated with vehicle, $0.403 \pm 0.055 v s 0.477 \pm 0.089 \mathrm{ng} / \mathrm{g}$, respectively (two-tailed $t$-test: $p=0.3109 ; t=1.043 ; \mathrm{df}=18 ; n=10$ animals per condition) (Figure $4 \mathrm{~b}$ ).
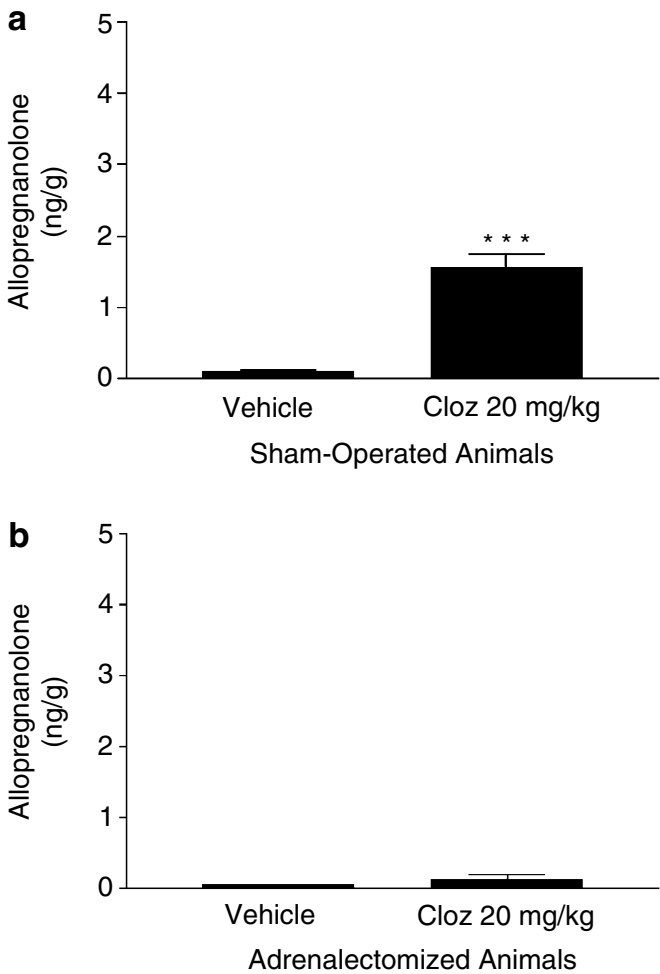

Figure 5 Clozapine $20.0 \mathrm{mg} / \mathrm{kg}$ increases cerebral cortical allopregnanolone in sham-operated animals, two-tailed $t$-test $* * * *<0.0001 ; t=6.964$; $\mathrm{df}=17, n=9-10$ animals per condition. (b) Adrenalectomy prevents clozapine-induced increases in cerebral cortical allopregnanolone, twotailed $t$-test $p=0.3109 ; t=1.043 ; \mathrm{df}=18, n=10$ animals per condition.

Very similar results were obtained utilizing clozapine in this experimental paradigm. Clozapine $20.0 \mathrm{mg} / \mathrm{kg}$ increases cerebral cortical allopregnanolone in sham-operated animals $(n=9)$ to $1.543 \pm 0.217 \mathrm{ng} / \mathrm{g}$ compared to levels in vehicle-treated sham-operated animals $(n=10)$ of $0.089 \pm 0.037 \mathrm{ng} / \mathrm{g} \quad$ (two-tailed $t$-test $\quad{ }^{* *} p<0.0001$; 
$t=6.964 ; \mathrm{df}=17) \quad$ (Figure 5a). Adrenalectomy prevents clozapine-induced increases in cerebral cortical allopregnanolone levels (Figure 5b). Allopregnanolone levels in adrenalectomized animals treated with clozapine $20.0 \mathrm{mg} /$ $\mathrm{kg}$ were very similar to adrenalectomized animals treated with vehicle, $0.125 \pm 0.076$ vs $0.046 \pm 0.006 \mathrm{ng} / \mathrm{g}$ (two-tailed $t$-test: $p=0.3109 ; t=1.043 ; \mathrm{df}=18, n=10$ animals per condition) (Figure 5b).

\section{DISCUSSION}

Olanzapine and Clozapine Effects on Cerebral Cortical Allopregnanolone

We have demonstrated that acute olanzapine and clozapine administration dose-dependently and specifically increases the GABAergic neuroactive steroid allopregnanolone in rat cerebral cortex to concentrations known to potentiate $\mathrm{GABA}_{\mathrm{A}}$ receptor function $(3.0-4.0 \mathrm{ng} / \mathrm{g}$ or $10-13 \mathrm{nM})$ (Majewska et al, 1986; Morrow et al, 1987, 1990). Allopregnanolone levels in the cerebral cortex following clozapine administration in these experiments are comparable to levels reported recently by Barbaccia et al (2001), utilizing 10.0 and $20.0 \mathrm{mg} / \mathrm{kg}$ dosing strategies. In contrast to olanzapine and clozapine, the antipsychotics risperidone and haloperidol had no significant effects on allopregnanolone levels in the cerebral cortex, confirming our initial hypothesis. We had predicted that both olanzapine and clozapine would increase the anxiolytic neuroactive steroid allopregnanolone, since these antipsychotics produce marked anxiolytic-like effects in rodent behavioral models. Since risperidone and haloperidol have minimal anxiolytic-like effects in these behavioral paradigms, we predicted that these antipsychotics would not alter rodent cortical allopregnanolone levels. It is therefore possible that olanzapine- and clozapine-induced elevations in the anxiolytic neuroactive steroid allopregnanolone contribute to the anxiolytic-like effects of these compounds. The absence of haloperidol-induced effects on this neuroactive steroid is consistent with recent efforts by Barbaccia et al (2001). To our knowledge, this is the first report demonstrating that acute risperidone administration does not affect central allopregnanolone levels.

We have not excluded the possibility that risperidone dosing greater than $1.0 \mathrm{mg} / \mathrm{kg}$ may be required to produce significant elevations in cerebral cortical allopregnanolone. Exceeding $1.0 \mathrm{mg} / \mathrm{kg}$ risperidone dosing in rodents would likely have limited clinical relevance, however, since $1.0 \mathrm{mg} /$ $\mathrm{kg}$ dosing of this compound produces $\mathrm{D}_{2}$ receptor occupancy greater than 90\% (Mukherjee et al, 2001) and considerable sedation. In humans, striatal $\mathrm{D}_{2}$ occupancy greater than $80 \%$ is associated with extrapyramidal side effects (Farde et al, 1992). This $90 \% \mathrm{D}_{2}$ occupancy rate following rodent $1.0 \mathrm{mg} / \mathrm{kg}$ dosing also exceeds $\mathrm{D}_{2}$ occupancy rates observed in human subjects receiving clinically therapeutic doses of risperidone. For example, patients with schizophrenia receiving $2.0-6.0 \mathrm{mg} /$ day of risperidone demonstrate $\mathrm{D}_{2}$ occupancy rates of $63-85 \%$ (Kapur et al, 1999). It is therefore unlikely that risperidone dosing greater than $1.0 \mathrm{mg} / \mathrm{kg}$ in rodents would yield clinically useful information.
These data suggest that olanzapine and clozapine may alter GABAergic neurotransmission by allopregnanolone induction, a possibility that may be relevant to the therapeutic actions of these compounds in patients with schizophrenia. Numerous studies examining postmortem tissue from subjects with schizophrenia suggest that GABAergic neurotransmission may be altered in the disorder, and that a deficiency in the GABA neurotransmitter system may be present (Benes and Berretta, 2001; Akbarian et al, 1995; Lewis, 2000). In addition, $\mathrm{GABA}_{\mathrm{A}}$ receptor agonists such as benzodiazepines are helpful in the treatment of schizophrenia in certain circumstances (Carpenter et al, 1999). Olanzapine- and clozapine-induced elevations in the GABAergic neuroactive steroid allopregnanolone may, therefore, represent a mechanism by which these compounds alter GABAergic neurotransmission in schizophrenia, possibly modulating this pathophysiologic component of the disorder and contributing to antipsychotic efficacy. The investigation of rodents treated with olanzapine and clozapine chronically will be necessary to determine if olanzapine- and clozapine-induced elevations in this neuroactive steroid persist with prolonged treatment and contribute to the long-term benefits of these antipsychotics.

Evidence suggests that allopregnanolone may also modulate dopaminergic neurotransmission. Specifically, allopregnanolone decreases stress-induced dopamine release in rodent cerebral cortex and nucleus accumbens (Motzo et al, 1996) and influences dopamine-mediated rodent behaviors (Khisti et al, 2002). The GABAergic neuroactive steroid $3 \alpha, 21$-dihydroxy-5 $\alpha$-pregnan-20-one (THDOC) also decreases stress-induced prefrontal cortical dopamine release (Grobin et al, 1992). Interestingly, recent evidence suggests that THDOC is also altered in subjects with depression; this neuroactive steroid appears to be increased during depression and decreased following antidepressant treatment, in contrast to allopregnanolone (Ströhle et al, 1999, 2000). Intraventricular allopregnanolone induces catalepsy in mice (Khisti et al, 1998), and this effect is reversed by GABAergic antagonists and dopaminergic agonists, and potentiated by the dopaminergic antagonist haloperidol. Allopregnanolone does not demonstrate activity at dopamine receptors, and therefore these effects on dopaminergic neurotransmission may be mediated by $\mathrm{GABA}_{\mathrm{A}}$ receptors. Allopregnanolone interactions with the dopamine neurotransmitter system may be important, since the dopamine hypothesis of schizophrenia has proved to be an enduring theoretical construct (Weinberger et al, 1988; Davis et al, 1991; Goldstein and Deutch, 1992), and recent imaging efforts have provided direct evidence that dopamine is altered in the disorder (Breier et al, 1997; Abi-Dargham et al, 1998, 2000).

In our experiments, adrenalectomy prevented olanzapineand clozapine-induced elevations in cerebral cortical allopregnanolone, suggesting that these effects are dependent on progesterone or allopregnanolone formation in the adrenal glands. Other recent efforts have also demonstrated that adrenalectomy prevents clozapine-induced cerebral cortical allopregnanolone formation (Barbaccia et al, 2001). We report for the first time that adrenalectomy also prevents olanzapine-induced elevations in this neuroactive steroid. Progesterone and allopregnanolone are lipophilic compounds, and several investigations have demonstrated that progesterone crosses the blood-brain barrier easily 
from the periphery into the central nervous system (Raisingham et al, 1968; Pepe and Rothchild, 1973; Karavolas et al, 1979). It is therefore possible that serum progesterone rapidly crosses the blood brain-barrier into the cerebral cortex prior to metabolism to allopregnanolone in the brain following acute treatment with olanzapine or clozapine. Our findings that serum progesterone levels are correlated with cerebral cortical allopregnanolone levels following olanzapine $(r=0.7649)$ and clozapine $(r=0.5583)$ administration support this possibility. Allopregnanolone production in the adrenal glands may also contribute to cerebral cortical allopregnanolone elevations, since this neuroactive steroid also crosses the blood-brain barrier readily.

The precise mechanisms leading to increased adrenal progesterone formation following treatment with olanzapine and clozapine are currently unclear. It is possible that olanzapine and clozapine act directly on adrenal enzymes leading to progesterone synthesis and significantly increase adrenal progesterone production in this manner. Alternatively, increased adrenal progesterone secretion may result from hypothalamic-pituitary-adrenal (HPA) axis activation. These possibilities will require further investigation.

In contrast, fluoxetine administration dose-dependently increases brain allopregnanolone levels in both adrenalectomized and intact rats, and therefore the absence of adrenal progesterone or allopregnanolone formation does not prevent or reduce this effect (Uzunov et al, 1996). Evidence indicates that fluoxetine increases allopregnanolone by acting directly on the $3 \alpha$-hydroxysteroid dehydrogenase ( $3 \alpha$-HSD) enzyme and maximizing its efficiency, resulting in enhanced allopregnanolone formation from its immediate precursor $5 \alpha$-dihydroprogesterone (Griffin and Mellon, 1999). It is not known currently if olanzapine or clozapine have similar effects on $3 \alpha$-HSD activity or if other mechanisms may be responsible for allopregnanolone induction following the administration of these antipsychotics. Further research examining olanzapine and clozapine effects on $3 \alpha$-HSD kinetics and $5 \alpha$-reductase activity will be required to explore the possibility of potential antipsychotic effects on the enzymes leading to allopregnanolone biosynthesis.

\section{Olanzapine and Clozapine Effects on Serum Progesterone}

Both olanzapine and clozapine produced marked dosedependent increases in serum progesterone up to 58- and 47-fold, respectively, in male rats. Risperidone had less marked effects (20-fold increases compared to vehicle at the highest dose tested) and haloperidol had minimal effects (2.7-fold increases compared to vehicle at the highest dose tested) on progesterone levels. While progesterone has been viewed most frequently in the context of ovarian secretion, adrenal synthesis appears to be functionally significant in rodents (Feder and Ruf, 1969; Walker et al, 2001) and may be relevant to nonreproductive functions in both males and females. For example, recent evidence suggests that progesterone actions contribute to central nervous system integrity. Progesterone has been reported to increase the number of oligodendrocytes expressing myelin basic protein (Jung-Testas et al, 1992, 1999), signal the initiation and enhance the rate of myelin formation (Chan et al, 1998), and increase remyelination following sciatic nerve injury (Koenig et al, 1995; Baulieu and Schumacher, 2000). Consequently, olanzapine- or clozapine-induced elevations in this steroid may be relevant to the regulation of myelination in the central nervous system.

Interestingly, evidence from DNA microarray efforts examining gene expression levels in postmortem dorsolateral prefrontal cortex suggests an alteration in the expression of myelination-related genes in schizophrenia and potential disruption in oligodendrocyte function (Hakak et al, 2001). Neuroimaging approaches also suggest that white matter integrity is altered in schizophrenia (Lim et al, 1998, 1999; Sigmundsson et al, 2001). Olanzapine- or clozapineinduced elevations in serum progesterone, a molecule with the capacity to cross the blood-brain barrier rapidly and influence oligodendrocyte myelination, may therefore play a role in modulating myelin formation in schizophrenia. Recent imaging evidence suggesting that olanzapine treatment in first-episode psychosis patients increases white matter volume (Lieberman et al, 2000) supports the possibility that olanzapine-mediated progesterone induction may be important in the pathophysiology and treatment of the disorder.

\section{Olanzapine and Clozapine Effects on Serum Corticosterone}

Olanzapine and clozapine also induced marked corticosterone elevations up to 10 - and 8.5-fold, respectively. Risperidone significantly increased corticosterone (3.7-fold compared to vehicle at the highest dose tested), but less markedly than olanzapine or clozapine. Haloperidol had more modest effects on corticosterone levels (2.4-fold increases compared to vehicle at the highest dose tested). The neurochemical mechanism responsible for this effect on the HPA axis is unclear and its potential clinical significance is currently unknown. The HPA axis appears to be altered in patients with schizophrenia (Meltzer et al, 2001), but the clinical literature is not conclusive (Marx and Lieberman, 1998). Schizophrenia is frequently characterized as a stress-sensitive illness, however, and stressful life events are associated with symptom exacerbation risk. It is therefore possible that antipsychotic-induced HPA axis alterations may be relevant to stress modulation in schizophrenia and antipsychotic treatment response. Accompanying elevations in cerebral cortical allopregnanolone may function to modulate this corticosterone response and ultimately suppress the HPA axis (Morrow et al, 1995), since allopregnanolone inhibits corticosterone release in rodents (Patchev et al, 1996; Guo et al, 1995).

Although corticosterone elevations are present following acute antipsychotic administration in rodents, it is uncertain if these effects persist with chronic treatment. In patients with schizophrenia treated with clozapine, cortisol levels were not elevated following treatment for 6 weeks compared to baseline (Breier et al, 1999), suggesting that these effects may not be present following chronic antipsychotic exposure. It is possible that clozapine- or olanzapine-induced cerebral cortical allopregnanolone may play a role in modulating acute corticosterone elevations and ensure the eventual return to lower levels of this steroid 
with prolonged antipsychotic treatment. Evidence that allopregnanolone decreases corticotropin-releasing factor (CRF) and adrenocorticotropin hormone (ACTH) in rodents supports this possibility (Patchev et al, 1994, 1996).

\section{RODENT DATA COMPARED TO HUMAN STUDIES}

HPA axis activation in rodents resulting in marked corticosterone and progesterone release is well-characterized, but very little information is available regarding stressinduced progesterone alterations in human male subjects. Similar to the rodent literature, however, stress appears to induce both progesterone and cortisol release in humans. For example, physical stress combined with sleep and calorie deprivation in males undergoing military endurance training results in significant progesterone and cortisol plasma elevations (Opstad, 1992). In addition, several studies have demonstrated that 2-deoxyglucose (2-DG) administration resulting in a clinical state similar to hypoglycemia also produces significant progesterone and cortisol elevations in healthy male subjects (Elman and Breier, 1997). Compared to the rodent stress response, these elevations are less pronounced, however, consisting of 2 to 3 -fold increases in progesterone and cortisol following this particular metabolic stressor. 2-DG-induced elevations in progesterone and cortisol have also been observed in male control subjects and patients with schizophrenia (Breier and Buchanan, 1992), and in healthy male subjects and abstinent alcoholic patients (George et al, 1994). Interestingly, patients with schizophrenia (drug-free 8-77 days, $n=9$ ) achieved significantly higher serum progesterone levels than control subjects following 2-DG administration, and tended to have higher baseline progesterone levels as well (Breier and Buchanan, 1992). Potential antipsychotic effects on peripheral progesterone levels in male patients with schizophrenia are currently unknown and will require further investigation.

Although the precise function and regulation of progesterone produced in the human adrenal have not been completely characterized, this neuroactive steroid may play an important role in the stress response and serve as a precursor to adrenal GABAergic neurosteroids such as allopregnanolone. For example, CRF challenge elevates both serum progesterone and allopregnanolone levels in human subjects (Genazzani et al, 1998). Interestingly, progesterone elevations in this study preceded allopregnanolone elevations by approximately $30 \mathrm{~min}$, suggesting that CRF challenge may result in progesterone metabolism to allopregnanolone in the adrenal. This sequence of events may be highly relevant to the regulation of the stress response, since rodent data suggest that allopregnanolone negatively modulates the HPA axis (Guo et al, 1995; Patchev et al, 1994, 1996). Recent evidence in human subjects demonstrating that allopregnanolone and cortisol levels are inversely related both at baseline and following mental stress also supports this possibility (Girdler et al, 2001).

It will also be important to determine if adrenal progesterone formation in humans is relevant to the regulation of allopregnanolone in the brain, potentially providing precursor for allopregnanolone biosynthesis in the central nervous system. Since many neuroactive steroids such as progesterone formed in the periphery cross the blood-brain barrier easily, the relative contribution of peripheral steroids to central neuroactive steroid formation in humans has been very difficult to determine. At this time, the dynamics of neurosteroid biosynthesis are largely unknown and this important research area will require future investigation.

\section{POTENTIAL CLINICAL RAMIFICATIONS OF OLANZAPINE- AND CLOZAPINE-INDUCED NEUROACTIVE STEROID ALTERATIONS}

Although clinical studies examining allopregnanolone in human subjects are currently limited in number, alterations in this neuroactive steroid in cerebrospinal fluid have been associated with improvement in depressive symptomatology (Uzunova et al, 1998). These findings may be relevant to schizophrenia, since depressive symptomatology frequently accompanies the illness (Keck et al, 2000). Interestingly, olanzapine appears to have antidepressant effects in patients with schizophrenia (Tollefson et al, 1997, 1998) and resistant major depression (Shelton et al, 2001). Clozapine also appears to have antidepressant effects, reducing suicidality, depression, and hopelessness in patients with schizophrenia (Meltzer and Okayli, 1995; Meltzer, 2001), and may be helpful in the treatment of psychotic depression (Ranjan and Meltzer, 1995). Given this clinical evidence suggesting that olanzapine and clozapine have antidepressant effects and data demonstrating the correlation of allopregnanolone levels with the alleviation of depressive symptoms (Uzunova et al, 1998), we suggest that olanzapine- and clozapine-induced increases in cerebral cortical allopregnanolone may contribute to the antidepressant effects of these two compounds.

In addition to these antidepressant actions, both olanzapine and clozapine appear to have antimanic and moodstabilizing properties in the treatment of bipolar disorder. Olanzapine recently received Federal Drug Administration approval for the treatment of acute manic episodes associated with bipolar disorder based on data from two placebo-controlled clinical trials (Tohen et al, 1999; McElroy et al, 1998), and may be effective in long-term treatment (Sanger et al, 2001). Clozapine also appears to have independent mood-stabilizing properties (Green et al, 2000; Suppes et al, 1999; Zarate et al, 1995). It is known that allopregnanolone has anticonvulsant effects in a number of seizure models, and anticonvulsants such as carbamazepine, valproic acid, and lamotrigine have demonstrated efficacy in the treatment of bipolar disorder. It is therefore possible that olanzapine- and clozapine-induced elevations in cerebral cortical allopregnanolone contribute to the antimanic and mood-stabilizing effects associated with these antipsychotics. Recent evidence that the anticonvulsant carbamazepine elevates cerebral cortical allopregnanolone supports the possibility that this neuroactive steroid may be relevant to mood stabilization in the treatment of bipolar disorder (Serra et al, 2000).

Allopregnanolone induction following antipsychotic administration may also be relevant to gender differences in schizophrenia illness course and treatment response. Specifically, most clinical studies indicate that females with schizophrenia have a more favorable response to 
antipsychotic treatment and lower relapse rates (Seeman, 1986, 1995, Angermeyer et al, 1990; Szymanski et al, 1995). The mechanisms responsible for these effects are not clear, but it has been suggested that higher serum drug levels in females receiving antipsychotics may contribute to these sex differences (Seeman, 1997). Higher drug levels in female patients with schizophrenia have been observed following fluphenazine decanoate (Simpson et al, 1990), clozapine (Szymanski et al, 1996), and olanzapine treatment (Kelly et al, 1999). Since olanzapine- and clozapine-induced allopregnanolone elevations appear to be dose-dependent, potential increases in this neuroactive steroid in females may be more pronounced in the setting of higher serum antipsychotic levels compared to males. In addition, allopregnanolone and its precursor progesterone are present in higher quantities in females compared to males (Paul and Purdy, 1992) and vary across the menstrual cycle (Genazzani et al, 1998). Olanzapine- and clozapine-induced allopregnanolone elevations may therefore be greater in females following antipsychotic treatment, secondary to higher baseline levels of these steroids in females and potential dose-related effects. Should allopregnanolone induction prove to be relevant to olanzapine or clozapine efficacy, higher allopregnanolone levels in females may contribute to the etiology of gender differences in antipsychotic treatment response.

\section{OVERVIEW}

In summary, olanzapine and clozapine have marked effects on cerebral cortical allopregnanolone, serum progesterone precursor, and serum corticosterone in these experiments. If the steroid milieu in the brain is also altered in humans following antipsychotic administration, pharmacologic treatment may result in neuroactive hormone effects in the central nervous system. Possible neurosteroid actions include the modulation of cerebral cortical GABAergic and dopaminergic neurotransmission, myelination processes, HPA axis activity, and gender-related treatment response.

\section{ACKNOWLEDGEMENTS}

This work was supported by an Investigator-Initiated Grant from Eli Lilly and Company, Indianapolis, Indiana (CEM), NIH Grants 5-R01-AA10564 (ALM), 2-P30-MH33127 (JAL), and 1-K23-MH65080 (CEM), and the National Alliance for Research on Schizophrenia and Affective Disorders (CEM).

\section{REFERENCES}

Abi-Dargham A, Gil R, Krystal J, Baldwin R, Seibyl J, Bowers M et al (1998). Increased striatal dopamine transmission in schizophrenia: confirmation in a second cohort. Am J Psychiatry 155: 761-767.

Abi-Dargham A, Rodenhiser J, Printz D, Zea-Ponce Y, Gil R, Kegeles LS et al (2000). Increased baseline occupancy of $\mathrm{D}_{2}$ receptors by dopamine in schizophrenia. Proc Natl Acad Sci USA 97: 8104-8109.

Akbarian S, Kim JJ, Potkin SG, Hagman JO, Tafazzoli A, Bunney WE et al (1995). Gene expression for glutamic acid decarbox- ylase is reduced without loss of neurons in prefrontal cortex of schizophrenics. Arch Gen Psychiatry 52: 258-266.

Angermeyer MC, Kuhn L, Goldstein JM (1990). Gender and the course of schizophrenia: differences in treated outcomes. Schizophrenia Bull 16: 293-307.

Arnt J (1995). Differential effects of classical and newer antipsychotics on the hypermotility induced by two dose levels of D-amphetamine. Eur J Pharmacol 283: 55-62.

Arnt J, Skarsfeldt T (1998). Do novel antipsychotics have similar pharmacological characteristics? A review of the evidence. Neuropsychopharmacology 18: 63-101.

Atkins JB, Chlan-Fourney J, Nye HE, Hiroi N, Carlezon WA, Nestler EJ (1999). Region-specific induction of $\Delta$ fosB by repeated administration of typical versus atypical antipsychotic drugs. Synapse 33: 118-128.

Barbaccia ML, Affricano D, Purdy RH, Maciocco E, Spiga F, Biggio G (2001). Clozapine, but not haloperidol, increases brain concentrations of neuroactive steroids in the rat. Neuropsychopharmacology 25: 489-497.

Baulieu E-E, Schumacher M (2000). Progesterone as a neuroactive neurosteroid, with special reference to the effect of progesterone on myelination. Steroids 65: 605-612.

Benes FM, Berretta S (2001). GABAergic interneurons: implications for understanding schizophrenia and bipolar disorder. Neuropsychopharmacology 25: 1-27.

Belelli D, Bolger MB, Kelvin GW (1989). Anticonvulsant profile of the progesterone metabolite $5 \alpha$-pregnan-3 $\alpha$-ol-20-one. Eur $J$ Pharmacol 166: 325-329.

Breier A, Buchanan RW (1992). The effects of metabolic stress on plasma progesterone in healthy volunteers and schizophrenic patients. Life Sci 51: 1527-1534.

Breier A, Su TP, Saunders R, Carson RE, Kolachana BS, deBartolomeis A et al (1997). Schizophrenia is associated with elevated amphetamine-induced synaptic dopamine concentrations. Proc Natl Acad Sci USA 94: 2569-2574.

Breier AF, Malhotra AK, Tung-Ping S, Pinals DA, Elman I, Adler CM et al (1999). Clozapine and risperidone in chronic schizophrenia: effects on symptoms, Parkinsonian side effects and neuroendocrine response. Am Jpsychiatry 156: 294-298.

Bymaster FP, Calligaro DO, Falcone JF, Marsh RD, Moore NA Tye NC et al (1996). Radioreceptor binding profile of the atypical antipsychotic olanzapine. Neuropsychopharmacology 14: 87-96.

Carpenter WT, Buchanan RW, Kirkpatrick B, Breier AF (1999). Diazepam treatment of early signs of exacerbation in schizophrenia. Am J Psychiatry 156: 299-303.

Chan JR, Phillips LJ, Glaser M (1998). Glucocorticoids and progestins signal the initiation and enhance the rate of myelin formation. Proc Natl Acad Sci USA 95: 10459-10464.

Crawley JN, Glowa JR, Majewska MD, Paul SM (1986). Anxiolytic activity of an endogenous adrenal steroid. Brain Res 398: 382-385.

Davis KL, Kahn RS, Ko G, Davidson M (1991). Dopamine in schizophrenia: a review and reconceptualization. Am J Psychiatry 148: 1474-1486.

Devaud LL, Purdy RH, Morrow AL (1995). The neurosteroid $3 \alpha-$ hydroxy-5 $\alpha$-pregnan-20-one, protects against bicuculline-induced seizures during ethanol withdrawal in rats. Alcoholism Clin Exp Res 19: 350-355.

Duncan GE, Miyamoto S, Leipzig JN, Lieberman JA (2000). Comparison of the effects of clozapine, risperidone, and olanzapine on ketamine-induced alterations in regional brain metabolism. J Pharmacol Exp Ther 29: 8-14.

Elman I, Breier A (1997). Effects of acute metabolic stress on plasma progesterone and testosterone in male subjects: relationship to pituitary-adrenocortical axis activation. Life Sci 61: 1705-1712. 
Farde L, Nordstrom AL, Wiesel FA, Pauli S, Halldin C, Sedvall G (1992). Positron emission tomographic analysis of central D1 and D2 dopamine receptor occupancy in patients treated with classical neuroleptics and clozapine: relation to extrapyramidal side effects. Arch Gen Psychiatry 49: 538-544.

Feder HH, Ruf KB (1969). Stimulation of progesterone release and estrous behavior by ACTH in ovariectomized rodents. Endocrinology 84: 171-174.

Finn DA, Gee KW (1994). The estrus cycle, sensitivity to convulsants and the anticonvulsant effect of a neuroactive steroid. J Pharmacol Exp Ther 271: 164-170.

Gasior M, Carter RB, Goldberg SR, Witkin JM (1997). Anticonvulsant and behavioral effects of neuroactive steroids alone and in conjunction with diazepam. J Pharmacol Exp Ther 282: 543-553.

Genazzani AR, Petragilia F, Bernardi F, Casarosa E, Salvestrone C, Tonetti A et al (1998). Circulating levels of allopregnanolone in humans: gender, age, and endocrine influences. J Clin Endocrinol Metab 83: 2099-2103.

George DT, Lindquist T, Alim T, Flood M, Eckardt MJ, Linnoila M (1994). Abstinent alcoholics exhibit an exaggerated stress response to 2-deoxy-D-glucose challenge. Alcoholism Clin Exp Res 18: 685-691.

Girdler SS, Straneva PA, Light KC, Pedersen CA, Morrow AL (2001). Allopregnanolone levels and reactivity to mental stress in premenstrual dysphoric disorder. Biol Psychiatry 49: 788-797.

Goldstein M, Deutch AY (1992). Dopaminergic mechanisms in the pathogenesis of schizophrenia. FASEB J 6: 2413-2421.

Green AI, Tohen M, Patel JK, Banov M, DuRand C, Berman I et al (2000). Clozapine in the treatment of refractory psychotic mania. Am J Psychiatry 157: 982-986.

Griffin LD, Mellon SH (1999). Selective serotonin reuptake inhibitors directly alter activity of neurosteroidogenic enzymes. Proc Natl Acad Sci USA 96: 13512-13517.

Grobin AC, Roth RH, Deutch AY (1992). Regulation of the prefrontal cortical dopamine system by the neuroactive steroid $3 \alpha, 21$-dihydroxy-5 $\alpha$-pregnane-20-one. Brain Res 578: 351-356.

Guo AL, Petraglia F, Criscuolo M, Ficarra G, Nappi RE, Palumbo MA (1995). Evidence for a role of neurosteroids in modulation of diurnal changes and acute stress-induced corticosterone secretion in rats. Gynecol Endocrinol 9: 1-7.

Hakak Y, Walker JR, Li C, Wong WH, Davis KL, Buxbaum JD et al (2001). Genome-wide expression analysis reveals dysregulation of myelination-related genes in chronic schizophrenia. Proc Natl Acad Sci USA 98: 4746-4751.

Inoue T, Tsuchiya K, Koyama T (1996). Effects of typical and atypical antipsychotic drugs on freezing behavior induced by conditioned fear. Pharmacol Biochem Behavior 55: 195-201.

Janis GC, Devaud LL, Mitsuyama H, Morrow AL (1998). Effects of chronic ethanol consumption and withdrawal on the neuroactive steroid $3 \alpha$-hydroxy-5 $\alpha$-pregnan-20-one in male and female rats. Alcoholism Clin Exp Res 22: 2055-2061.

Janssen PA, Niemegeers CJ, Awouters F, Schellekens KH, Megens AA, Meert TF (1988). Pharmacology of risperidone (R64 766), a new antipsychotic with serotonin-S2 and dopamine-D2-antagonistic properties. J Pharmacol Exp Ther 244: 685-693.

Jung-Testas I, Do Thi A, Koenig H, Desarnaud F, Shazand K, Schumacher M (1999). Progesterone as a neurosteroid: synthesis and actions in rat glial cells. J Steroid Biochem Mol Biol 69: 97-107.

Jung-Testas I, Renoir M, Bugnard H, Greene GL, Baulieu E-E (1992). Demonstration of steroid hormone receptors and steroid action in primary cultures of rat glial cells. J Steroid Biochem Mol Biol 41: 621-631.

Kapur K, Zipursky RB, Remington G (1999). Clinical and theoretical implications of $5-\mathrm{HT}_{2}$ and $\mathrm{D}_{2}$ receptor occupancy of clozapine, risperidone, and olanzapine in schizophrenia. $\mathrm{Am} \mathrm{J}$ Psychiatry 156: 286-293.
Kapur S, Zipursky RB, Remington G, Jones C, DaSilva J, Wilson AA et al (1998). $5-\mathrm{HT}_{2}$ and $\mathrm{D}_{2}$ receptor occupancy of olanzapine in schizophrenia: a PET investigation. Am J Psychiatry 155: 921-928.

Karavolas HJ, Hodges DR, O'Brien DJ, Mackenzie KM (1979). In vivouptake of $\left[{ }^{3} \mathrm{H}\right]$ progesterone and $\left[{ }^{3} \mathrm{H}\right]-5 \alpha$-dihydroprogesterone by rat brain and pituitary and effects of estradiol and time: tissue concentration of progesterone itself of specific metabolites? Endocrinology 104: 1418-1425.

Keck PE, Strakowski SM, McElroy SL (2000). The efficacy of atypical antipsychotics in the treatment of depressive symptoms, hostility, and suicidality in patients with schizophrenia. J Clin Psychiatry 61(Suppl 3): 4-9.

Kelly DL, Conley RR, Tamminga CA (1999). Differential olanzapine plasma concentrations by sex in a fixed-dose study. Schizophrenia Res 40: 101-104.

Khisti RT, Deshpande LS, Chopde CT (2002). The neurosteroid $3 \alpha-$ hydroxy- $5 \alpha$-pregnan-20-one affects dopamine mediated behavior in rodents. Psychopharmacology 161: 120-128.

Khisti RT, Mandhane SN, Chopde CT (1998). The neurosteroid $3 \alpha$ hydroxy-5 $\alpha$-pregnan-20-one induces catalepsy in mice. Neurosci Lett 251: 85-88.

Kinkead B, Shahid S, Owens MJ, Nemeroff CB (2000). Effects of acute and subchronic administration of typical and atypical antipsychotic drugs on the neurotensin system of the rat brain. $J$ Pharmacol Exp Ther 295: 67-73.

Koenig HL, Schumacher M, Ferzaz B, Do Thi AN, Ressouches A, Guennoun $\mathrm{R}$ et al (1995). Progesterone synthesis and myelin formation by Schwann cells. Science 268: 1500-1503.

Kokate TG, Cohen AL, Karp E, Rogawski MA (1996). Neuroactive steroids protect against pilocarpine- and kainic acid-induced limbic seizures and status epilepticus in mice. Neuropharmacology 35: 1049-1056.

Kokate TG, Svensson BE, Rogawski MA (1994). Anticonvulsant activity of neurosteroids: correlation with gamma-aminobutyric acid-evoked chloride current potentiation. J Pharmacol Exp Ther 270: $1223-1229$.

Lewis DA (2000). GABAergic local circuit neurons and prefrontal cortical dysfunction in schizophrenia. Brain Res Rev 31: 270-276.

Lieberman JA, Tohen M, McEvoy J, Sanger T, Keefe R, Charles H et al the HGDH Study Group (2000). Olanzapine versus haloperidol in the treatment of first-episode psychosis. Abstracts of the 39th American College of Neuropsychopharmacology Meeting, December 2000.

Lim KO, Adalsteinsson E, Spielman D, Sullivan EV, Rosenbloom MJ, Pfefferbaum A (1998). Proton magnetic resonance spectroscopic imaging of cortical gray and white matter in schizophrenia. Arch Gen Psychiatry 55: 346-352.

Lim KO, Hedehus M, Moseley M, de Crespigny A, Sullivan EV, Pfefferbaum A (1999). Compromised white matter tract integrity in schizophrenia inferred from diffusion tensor imaging. Arch Gen Psychiatry 56: 367-374.

Majewska MD, Harrison NL, Schwartz RD, Barker JL, Paul SM (1986). Steroid hormone metabolites are barbiturate-like modulators of the GABA receptor. Science 232: 1004-1007.

Marx CE, Duncan GE, Gilmore JH, Lieberman JA, Morrow AL (2000). Olanzapine increases allopregnanolone in the rat cerebral cortex. Biological Psychiatry 47: 1000-1004.

Marx CE, Lieberman JA (1998). Psychoneuroendocrinology of schizophrenia. In: Nemeroff C (ed). Psychiatric Clinics of North America. WB Saunders, Philadelphia, PA 21: 413-434.

McElroy SL, Frye M, Denicoff K, Altshuler L, Nolen W, Kupka R et al (1998). Olanzapine in treatment-resistant bipolar disorder. $J$ Affect Disord 49: 119-122.

Megens AA, Awouters FH, Schotte A, Meert TF, Dugovic C, Niemegeers CJ et al (1994). Survey on the pharmacodynamics of the new antipsychotic risperidone. Psychopharmacology 114: 9-23. 
Meltzer HY (2001). Treatment of suicidality in schizophrenia. Ann NY Acad Sci 932: 44-58.

Meltzer HY, Myung AL, Jayathilake K (2001). The blunted plasma cortisol response to apomorphine and its relationship to treatment response in patients with schizophrenia. Neuropsychopharmacology 24: 278-290.

Meltzer HY, Okayli G (1995). Reduction of suicidality during clozapine treatment of neuroleptic-resistant schizophrenia: impact on risk-benefit assessment. Am J Psychiatry 152: 183-190.

Moore NA, Rees G, Sanger G, Tye NC (1994). Effects of olanzapine and other antipsychotic agents on responding maintained by a conflict schedule. Behav Pharmacol 5: 196-202.

Moore NA, Tye NC, Axton MS, Risius FC (1992). The behavioral pharmacology of olanzapine, a novel 'atypical' antipsychotic agent. J Pharmacol Exp Ther 262: 545-551.

Morrow AL, Devaud LL, Purdy RH, Paul SM (1995). Neuroactive steroid modulators of the stress response. Ann NY Acad Sci 771: 257-272.

Morrow AL, Pace JR, Purdy RH, Paul SM (1990). Characterization of steroid interactions with gamma-aminobutyric acid receptorgated chloride ion channels: evidence for multiple steroid recognition sites. Mol Pharmacol 37: 263-270.

Morrow AL, Suzdak PD, Paul SM (1987). Steroid hormone metabolites potentiate GABA receptor-mediated chloride ion flux with nanomolar potency. Eur J Pharmacol 142: 483-485.

Motzo C, Porceddu ML, Maira G, Flore G, Concas A, Dazzi L et al (1996). Inhibition of basal and stress-induced dopamine release in the cerebral cortex and nucleus accumbens of freely moving rats by the neurosteroid allopregnanolone. J Psychopharmacol 10: 266-272.

Mukherjee J, Christian BT, Narayanan TK, Bingzhi S, Mantil J (2001). Evaluation of dopamine D-2 receptor occupancy by clozapine, risperidone, and haloperidol in vivoin the rodent and nonhuman primate brain using ${ }^{18} \mathrm{~F}$-fallypride. Neuropsychopharmacology 25: 476-488.

Opstad PK (1992). Androgenic hormones during prolonged physical stress, sleep, and energy deficiency. J Clin Endocrinol Metab 74: 1176-1183.

Patchev VK, Hassan AHS, Holsboer F, Almeida OFX (1996). The neurosteroid tetrahydroprogesterone attenuates the endocrine response to stress and exerts glucocorticoid-like effects on vasopressin gene transcription in the rat hypothalamus. Neuropsychopharmacology 15: 533-540.

Patchev VK, Shoaib M, Holsboer F, Almeida OFX (1994). The neurosteroid tetrahydroprogesterone counteracts corticotropinreleasing hormone-induced anxiety and alters the release and gene expression of corticotropin-releasing hormone in the rat hypothalamus. Neuroscience 62: 265-271.

Paul SM, Purdy RH (1992). Neuroactive steroids. FASEB J 6: 2311-2322.

Pepe GJ, Rothchild I (1973). Metabolic clearance rate of progesterone: comparison between ovariectomized, pregnant, pseudopregnant and deciduoma-bearing pseudopregnant rats. Endocrinology 93: 1200-1205.

Purdy RH, Moore PH, Rao PN, Hagino N, Yamaguchi T, Schmidt P et al (1990). Radioimmunoassay of $3 \alpha$-hydroxy- $5 \alpha$-pregnan-20one in rat and human plasma. Steroids 55: 290-296.

Purdy RH, Morrow AL, Moore PH, Paul SM (1991). Stress-induced elevations of $\gamma$-aminobutyric acid type A receptor-active steroids in the rat brain. Proc Natl Acad Sci USA 88: 4553-4557.

Raisingham KH, Dorfman R, Forchielli E, Gyermak L, Genther G (1968). Uptake of intravenously administered progesterone, pregnanedione and pregnanolone by the rat brain. Acta Endocrinol 57: 395-404.

Ranjan R, Meltzer HY (1995). Acute and long-term effectiveness of clozapine in treatment-resistant psychotic depression. Biol Psychiatry 40: 253-258.
Romeo E, Str A, Spalletta G, di Michele F, Hermann B, Holsboer F et al (1998). Effects of antidepressant treatment on neuroactive steroids in major depression. Am J Psychiatry 155: 910-913.

Sanger TM, Grundy SL, Gibson PJ, Namjoshi MA, Greaney MG, Tohen MF (2001). Long-term olanzapine therapy in the treatment of bipolar I disorder: an open-label continuation phase study. J Clin Psychiatry 62: 273-281.

Seeman M (1986). Current outcome in schizophrenia: women $v s$ men. Acta Psychiatr Scand 73: 609-617.

Seeman M (1995). Gender differences in treatment response to schizophrenia. In: Seeman MV (ed). Gender and Psychopathology. Washington, DC: American Psychiatric Press, pp 227-268.

Seeman MV (1997). Psychopathology in women and men: focus on female hormones. Am J Psychiatry 154: 1641-1647.

Serra M, Littera M, Pisu MG, Muggironi M, Purdy RH, Biggio G (2000). Steroidogenesis in rat brain induced by short- and longterm administration of carbamazepine. Neuropharmacology 39: 2448-2456.

Shelton RC, Tollefson GD, Tohen M, Stahl S, Gannon KS, Jacobs TG et al (2001). A novel augmentation strategy for treating resistant major depression. Am J Psychiatry 158: 131-134.

Sigmundsson T, Suckling J, Maier M, Williams SCR, Bullmore ET, Greenwood KE et al (2001). Structural abnormalities in frontal, temporal, and limbic regions and interconnecting white matter tracts in schizophrenic patients with prominent negative symptoms. Am J Psychiatry 158: 234-243.

Simpson GM, Yadalam KG, Levinson DF, Stephanos MJ, Lo ES, Cooper TB (1990). Single dose pharmacokinetics of fluphenazine after fluphenazine decanoate administration. J Clin Psychopharmacol 10: 417-421.

Spealman RD, Katz JL (1980). Some effects of clozapine on punished responding by mice and squirrel monkeys. J Pharmacol Exp Ther 212: 435-440.

Ströhle A, Pasini A, Romeo E, Hermann B, Spalletta G, di Michele F et al (2000). Fluoxetine decreases concentrations of $3 \alpha, 5 \alpha$ tetrahydrodeoxycorticosterone (THDOC) in major depression. $J$ Psychiatric Res 34: 183-186.

Ströhle A, Romeo E, Hermann B, Pasini A, Spalletta G, di Michele F et al (1999). Concentrations of $3 \alpha$-reduced neuroactive steroids and their precursors in plasma of patients with major depression and after clinical recovery. Biol Psychiatry 45: 274-277.

Suppes T, Webb A, Paul B, Carmody T, Kraemer H, Rush AJ (1999). Clinical outcome in a randomized 1-year trial of clozapine versus treatment as usual for patients with treatment-resistant illness and a history of mania. Am J Psychiatry 156: $1164-1169$.

Szymanski S, Lieberman JA, Alvir JM, Mayerhoff D, Loebel A, Geisler S et al (1995). Gender differences in onset of illness, treatment response, course, and biologic indexes in first-episode schizophrenic patients. Am J Psychiatry 152: 698-703.

Szymanski S, Lieberman JA, Pollack S, Kane JM, Safferman A, Munne $\mathrm{R}$ et al (1996). Gender differences in neuroleptic nonresponsive clozapine-treated schizophrenics. Biol Psychiatry 39: 249-254.

Tohen M, Jacobs TG, Grundy SL, McElroy SL, Banov MC, Janicak PG et al for the Olanzapine HGGW Study Group (2000). Efficacy of olanzapine in acute bipolar mania: a double-blind, placebocontrolled study. Arch Gen Psychiatry 57: 841-849.

Tohen M, Sanger TM, McElroy SL, Tollefson GD, Chengappa RKN, Daniel DG et al the Olanzapine HGEH Study Group (1999). Olanzapine versus placebo in the treatment of acute mania. Am J Psychiatry 156: 702-709.

Tollefson GD, Beasley CM, Tran PV, Street JS, Krueger JA, Tamura RN et al (1997). Olanzapine versus haloperidol in the treatment of schizophrenia and schizoaffective and schizophreniform disorders: results of an international collaborative trial. $\mathrm{Am} J$ Psychiatry 154: 457-465. 
Tollefson GD, Sanger TM, Beasley CM, Tran PV (1998). A doubleblind, controlled comparison of the novel antipsychotic olanzapine versus haloperidol or placebo on anxious and depressive symptoms accompanying schizophrenia. Biol Psychiatry 43: 803-810.

Uzunov DP, Cooper TB, Costa E, Guidotti A (1996). Fluoxetineelicited changes in brain neurosteroid content measured by negative ion mass fragmentography. Proc Natl Acad Sci USA 93: 12599-12604.

Uzunova V, Sheline Y, Davis JM, Rasmusson A, Uzunov DP, Costa E, Guidotti A (1998). Increase in the cerebrospinal fluid content of neurosteroids in patients with unipolar major depression who are receiving fluoxetine or fluvoxamine. Proc Natl Acad Sci USA 95: 3239-3244.

VanDoren MJ, Matthews DB, Janis GC, Grobin AC, Devaud LL, Morrow AL (2000). Neuroactive steroid $3 \alpha$-hydroxy- $5 \alpha$-pregnan20-one modulates electrophysiological and behavioral actions of ethanol. J Neurosci 20: 1982-1989.

Walker DQ, Francis R, Cabassa J, Kuhn CM (2001). Effect of ovarian hormones and estrous cycle on stimulation of the hypothalamo-pituitary-adrenal axis by cocaine. J Pharmacol Exp Ther 297: 291-298.
Weinberger DR, Berman KF, Illowsky BP (1988). Physiological dysfunction of dorsolateral prefrontal cortex in schizophrenia: III. A new cohort and evidence for a monoaminergic mechanism. Arch Gen Psychiatry 45: 609-615.

Wieland S, Lan NC, Mirasedeghi S, Gee KW (1991). Anxiolytic activity of the progesterone metabolite $5 \alpha$-pregnan-3 $\alpha$-ol-20-one. Brain Res 565: 263-268.

Wiley JL, Compton AD, Porter JH (1993). Effects of four antipsychotics on punished responding in rats. Pharmacol Biochem Behav 45: 263-267.

Zarate CA, Tohen M, Baldessarini RJ (1995). Clozapine in severe mood disorders. J Clin Psychiatry 56: 411-417.

Zhang W, Bymaster FP (1999). The in vivo effects of olanzapine and other antipsychotic agents on receptor occupancy and antagonism of dopamine $\mathrm{D}_{1}, \mathrm{D}_{2}, \mathrm{D}_{3}, 5 \mathrm{HT}_{2 \mathrm{~A}}$ and muscarinic receptors. Psychopharmacology 141: 267-278.

Zhang W, Perry KW, Wong DT, Potts BD, Bao J, Tollefson GD et al (2000). Synergistic effects of olanzapine and other antipsychotic agents in combination with fluoxetine on norepinephrine and dopamine release in rat prefrontal cortex. Neuropsychopharmacology 23: 250-262. 